\title{
HYDRAULIC FRACTURING AND PROTECTION OF FRESHWATER RESOURCES IN THE GREAT LAKES STATE
}

\author{
Nicholas J. Schroeck ${ }^{1}$ \\ I. INTRODUCTION TO HYDRAULIC FRACTURING AND \\ GREAT LAKES WATER RESOURCES
}

Hydraulic fracturing, also known as "fracking," is a commonly used oil and natural gas well stimulation process used to maximize extraction. ${ }^{2}$ Fracking, in its most basic sense, involves drilling very deep wells into the earth and filling the chasm with a mixture of water, sand, and various chemicals. ${ }^{3}$ The fracking fluid mixture, when pumped in at the required pressures, causes layers of rock to crack and fill with particles and lubricants from the fluid, creating fissures within the rock that allow natural gas to escape for extraction. ${ }^{4}$ This process has revolutionized the oil and natural gas energy industry when combined with horizontal drilling techniques, unlocking decades of fuel that was once nearly unattainable. ${ }^{5}$

Despite the potential benefits of increased domestic oil and gas extraction and well productivity gained by utilizing the fracking process, the process remains controversial. ${ }^{6}$ Numerous environmental questions remain unanswered, including disposal of the contaminated used fracking fluid, the integrity of well casings, and the impacts to local watersheds from large-quantity groundwater withdrawals. ${ }^{7}$ This short list of environmental concerns is by no means exhaustive, but this Article will focus on water

1. (C) 2013, Nicholas J. Schroeck. Executive Director, Great Lakes Environmental Law Center, Adjunct Professor, Wayne State University Law School. Thank you to Tahoe McGuire, University of Toledo, College of Law (May 2014) for her research assistance and to Noah D. Hall, Associate Professor, Wayne State University Law School, for his comments and suggestions on the draft. Thanks to the students at the Indiana International and Comparative Law Review for putting on a fantastic symposium on the many challenges facing the Great Lakes. Ryan Schutte, Staff Attorney, Meridian Health Plan. Elizabeth Arnkoff, Attorney, Lexis Account Executive.

2. See generally The Process of Hydraulic Fracturing, U.S. EPA, $\mathrm{http}: / / \mathrm{www} 2$.epa.gov/hydraulicfracturing/process-hydraulic-fracturing (last updated May 21, 2013, archived at http://perma.cc/T6NJ-FW2A).

3. See id.

4. See id.

5. See Questions and Answers About Hydraulic Fracturing in Michigan, MICH. DEPT. OF ENVTL. QUALITY, http://www.michigan.gov/documents/deq/deq-FINAL-frackQA_384089_7.pdf (last visited Dec. 23, 2013, archived at http://perma.cc/Y7JR-XT36).

6. See U.S. EPA, Study of the Potential Impacts of Hydraulic Fracturing on DRINKING WATER RESOURCES: PROGRESS REPORT 5 (2012), archived at http://perma.cc/BA37-PTJM.

7. See id. 
quality and quantity issues related to fracking. Economically, fracking has revolutionized an industry, and the boom has caused natural gas prices to plummet to levels unheard of just a few years ago. ${ }^{8}$

This Article seeks to provide reasonable, common sense methods to better regulate this important technology by using the regulations of the State of Michigan, which is surrounded by the Great Lakes, as an example. There are regulatory gaps at the local, state, and federal level. ${ }^{9}$ As fracking technology matures and expands, so should protections to ensure that this extraction process is utilized in ways that limit the potential impacts on human health and the environment. In that regard, Michigan should provide a more comprehensive permitting process and more rigorous water quality testing. Where state and the federal government have failed to act, local units of government in Michigan retain significant power through "Home Rule"10 provisions to regulate fracking within their jurisdictions.

Michigan, two peninsulas surrounded by the Great Lakes, has experienced a boom of new oil and natural gas well development since 2010. ${ }^{11}$ The Great Lakes form the largest freshwater system on the Earth, holding approximately 84 percent of North America's surface freshwater and 21 percent of the world's surface freshwater supply. ${ }^{12}$ The Great Lakes provide drinking water for forty million people and are essential for the region's agriculture and manufacturing sectors. ${ }^{13}$ The environmental and economic importance of the Great Lakes, Michigan's unique geographic position at the center of such an amazing resource, together with the increase of fracking operations in the state, underscore the need for effective regulation of oil and gas development.

\section{STATE REGULATION OF HYDRAULIC FRACTURING}

In the absence of strong federal regulation of fracking, ${ }^{14}$ states have

8. Meghan Foley, Domestic Natural Gas: From Boom to Overkill, USA TODAY, http://www.usatoday.com/story/money/business/2013/08/25/natural-gas-boom-overkill/2692767 (Aug. 25, 2013, archived at http://perma.ce/4V94UGDD).

9. See Hannah Wiseman, Untested Waters: The Rise of Hydraulic Fracturing in Oil and Gas Production and the Need to Revisit Regulation, 20 FoRDHAM ENVTL. L. REV. 115, 116 (2009).

10. The LAW DictionaRY, http://thelawdictionary.org/home-rule/ (last visited Oct. 10, 2013, archived at http://perma.cc/Y7E6-NDW3).

11. Nicholas Schroeck \& Stephanie Karisny, Hyrdaulic Fracturing and Water Management in the Great Lakes, 63 CASE W. RES. L. REV. 1167, 1171 (2013).

12. Great Lakes Fact Sheet, ENVTL. PROTECTION AGENCY, http://www.epa.gov/ greatlakes/factsheet.html (last updated July 5, 2012, archived at http://perma.cc/BWB6$3 \mathrm{NXU})$.

13. About Our Great Lakes: Great Lakes Basin Facts, NAT'L OCEANIC AND ATMOSPHERIC ADMIN., http://www.glerl.noaa.gov/pr/ourlakes/facts.html (last visited Nov. 1, 2013, archived at http://perma.cc/G785-2UDC).

14. See Schroeck \& Karisny, supra note 11 , at 1170. 
had to step in and provide additional environmental protections. While the federal government has failed to closely regulate the industry, many states have also not committed to the task. ${ }^{15}$ Some states, like New York, ${ }^{16}$ have started the process of crafting a specific regulatory program for differentiating fracturing from other methods of oil and natural gas extraction. Michigan has also regulated fracking but significant gaps remain. $^{17}$

\section{A. Statutory Authority for Oil and Gas Development in Michigan}

The Michigan Department of Environmental Quality (DEQ) and the Michigan Public Service Commission (MPSC) are the state agencies in charge of oil and gas well permits. ${ }^{18}$ The DEQ issues initial permits for oil and natural gas wells, ${ }^{19}$ and the MPSC regulates the transport of oil and gas through existing or new pipelines. ${ }^{20}$ Though the MPSC is part of the process, it is not nearly as integral to the regulation of oil and gas drilling as the DEQ. ${ }^{21}$

The statutory requirements for Michigan oil and natural gas wells are contained in part 615 of the Natural Resources and Environmental Protection Act (NREPA). ${ }^{22}$ Specifically, NREPA grants authority to the Supervisor of Wells (Supervisor), the state official formally charged with regulating oil and gas development. ${ }^{23}$ There is pending legislation in the Michigan House of Representatives that would alter the regulatory landscape, but the path for its adoption into law is unclear. ${ }^{24}$

\section{B. The Michigan Department of Environmental Quality Permitting Process}

Michigan fracking regulations continue to evolve over time as pressure from the public and other stakeholders influence the DEQ. The

15. Id. at 1171 .

16. High Volume Hydraulic Fracturing Proposed Regulations, NEW YORK STATE DEP'T OF ENVTL. CONSERVATION, http://www.dec.ny.gov/regulations/77353.html (last visited Nov. 1, 2013, archived at http://perma.cc/WG5G-87M8).

17. See Stephanie Karisny, Hydraulic Fracturing in Michigan: Reassessing State Regulations in Light of New Drilling in the Collingwood and Utica Shales, 57 WAYNE L. REV. 627, 649 (2011) (discussing many of the perceived deficiencies in the Michigan law as it currently stands, along with suggesting future revisions).

18. Id. at 638 .

19. MiCH. COMP. LAWS $\S \S 324.61505 a, 324.61506$ (2013).

20. MiCH. ADMIN. CoDE r 460.864 (2013).

21. See Mich. Dept. of Envtl. Quality, Who Does What List, Mich.Gov 25-26, http://www.michigan.gov/documents/deq/dnre-whodoeswhat_316972_7.pdf. (last updated Dec. 16, 2013, archived at http://perma.cc/Q3GJ-7A39).

22. MicH. COMP. LAWS $\S \S 324.61505-324.61527$ (2013).

23. Id. $\S \S 324.61503,324.61505$.

24. H.R. 4122, 97th Leg. (Mich. 2013). 
DEQ has taken steps to reform its oil and gas drilling regulations as the process has gained notoriety by adding additional requirements. Most recently, the Supervisor issued the "Supervisor of Wells Instruction 1$2013, " 25$ which provides rules specifically for high-volume fracking. These rules supplement the general rules for oil and gas extraction contained in Part 615 through Part 617 of Michigan's Natural Resources and Environmental Protection Act 451 of the Public Acts of $1994 .^{26}$ The DEQ has published permit to drill and operate requirements in the Michigan Administrative Code chapter 324 , sections 201 through $216 .{ }^{27}$ Here, the regulations indicate specific requirements for obtaining a drilling permit ${ }^{28}$ deepening permit, ${ }^{29}$ storage permit, $^{30}$ and bonding and financial responsibility. ${ }^{31}$ Additionally, the DEQ has produced a series of FAQs for drilling groups, explaining the agency's interpretation of several of the rules. ${ }^{32}$

Initially, the Supervisor must investigate the exact location for the well as described by the drilling entity in order to survey the natural features surrounding the site. ${ }^{33}$ The rules require additional DEQ permitting for a well that is to go near a surface water body or that is located in a floodplain. ${ }^{34}$ Most importantly to concerned citizens, the driller must indicate the kinds of fluids to be used, including a chemical analysis indicating levels of stated chemicals, unless the driller is merely utilizing fresh water. ${ }^{35}$ The drilling entity must also create and disclose the well's plugging and abandonment plan prior to receiving the permit. ${ }^{36}$ Use of horizontal drilling techniques must be disclosed to the Supervisor. ${ }^{37}$ Finally, once a permit is granted, the drilling entity must post the permit in a conspicuous place at the well location until the well has been completed. ${ }^{38}$

Once a permit has been granted, any change in well location, method of drilling, depth of well, or a transfer of well ownership must be disclosed

25. Mich. Dept. OF ENVTl. Quality, SuPERVisor OF Wells InStruction 1-2013 (2013), archived at $\mathrm{http}: / /$ perma.cc/02LF2Ndz5aY.

26. See id.

27. Mich. ADMIN. CODE r 324.201-216 (2013).

28. MiCH. ADMIN. CODE r 324.201.

29. Id. $\mathrm{r} 324.206$.

30. Id. $\mathrm{r} 324.204$.

31. Id. $\mathrm{r} 324.210$.

32. Rules FAQ and Answers, Mich. DEPT. OF ENVTL. Quality, http://www.michigan.gov/deq/0,1607,7-135-3311_4111_4231-9171--,00.html (last visited Nov. 1, 2013, archived at http://perma.cc/7VMM-AVLZ).

33. MiCH. ADMIN. CODE r 324.201(2) (2013).

34. Id.

35. Id. The current chemical list includes: cations, anions, calcium, chloride, sodium, sulfate, magnesium, bicarbonate, and potassium. Id.

36. Id.

37. Id.

38. Id. 
and permission obtained from the Supervisor. ${ }^{39}$ Drillers must obtain bonding of up to $\$ 250,000$ based on depth of the well; however, if a person has multiple wells and the aggregate bonding would be greater than $\$ 250,000$, one blanket conformance bond may be used to cover all of the wells up to 100 per blanket policy. ${ }^{40}$ The regulations also dictate spacing limitations, requiring the drilling unit for wells at a legal subdivision of forty acres, as well as other requirements for spacing of the bottom hole from the edge of the zone and from other wells, including fresh water wells, or existing structures. ${ }^{41}$ There are numerous exceptions to the spacing requirements, including anti-waste exceptions, freshwater well or existing structure owner consent, and pooling of mineral interests. ${ }^{42}$

When extraction is completed, the health and environmental risks do not go away, and wells must be carefully plugged or otherwise decommissioned. ${ }^{43}$ The DEQ regulations contemplate specific procedures that must be followed to properly end the well's use, and the Supervisor is involved throughout the process. ${ }^{44}$ Once the Supervisor has been notified, he or she must issue instructions to the drilling entity containing a series of technical requirements promulgated in the statute. ${ }^{45}$ Plugging must commence for wells that have not been used for twelve consecutive months, have permits that have lapsed for greater than twelve months, where drilling has been completed, or where the well has become a dry hole. ${ }^{46}$

In response to the fracking boom, the Michigan oil and gas permitting system has improved over the last few years as a result of strong advocacy from both environmental and public interest groups and evolving industry best practices, ${ }^{47}$ but there are still many areas for improvement.

\section{MUNICIPAL AUTHORITY TO REgUlATE OIL AND GAS DEVELOPMENT IN MICHIGAN}

Local units of government derive power from the Michigan State Constitution, Article VII. ${ }^{48}$ As a general rule, local units of government gain more power as they become more localized; the county has the least ability

39. Id. $\mathrm{r} 324.206$.

40. Id. $\mathrm{r} 324.212$.

41. Id. $\mathrm{r} 324.301$.

42. Id.

43. Mich. ADMIN. CODE r 324.902 (2013).

44. Even before an energy company decides to plug a well, it must first notify the Supervisor. Id. $\mathrm{r} 324.901$.

45. Id. $\mathrm{r} 324.902$.

46. Id. $\mathrm{r} 324.903$.

47. See Questions and Answers About Hydraulic Fracturing in Michigan, supra note 5.

48. MICH. CONST. art. VII, § 22. 
to regulate and the city has the greatest. ${ }^{49}$ Essentially, there are two designations, with sub-designations between them. The largest units are counties. ${ }^{50}$ A county's power is specified and limited in the Constitution and enabling legislation. ${ }^{51}$ Townships are an intermediary designation between statutory counties and home rule cities and villages, but townships are similar to counties in that they only have those powers specified by state enabling legislation. ${ }^{52}$ Cities and villages, on the other hand, while also owing all of their power to the state, have authority granted by the adoption of a city or village charter. Both cities and villages are granted "Home Rule" under the Constitution. ${ }^{53}$ The distinctions between local units of government result in differing powers and abilities to regulate, even for purely local affairs. ${ }^{54}$

Counties and townships, while they may adopt a charter under specific Michigan authorizing legislation, do not have constitutionally derived charter power, but a lesser, statutorily derived power. ${ }^{55}$ Charter townships and charter counties are an intermediary between "Home Rule" cities and non-charter townships and counties, respectively, with some of the powers of the former but still without wider regulatory authority as seen in the latter. ${ }^{56}$ Where two local units of government overlap and have conflicting ordinances, generally the city or village ordinance controls, but where the conflict is between a township and a county, the township ordinance controls. ${ }^{57}$ Townships and counties are granted power to create ordinances and zoning plans through the Michigan Zoning Enabling Act (ZEA). ${ }^{58}$

Cities and villages have the greatest potential to self-regulate ${ }^{59}$ but the lowest likelihood of actually having fracking operations within their jurisdictional borders. ${ }^{60}$ This is not a simple jurisdictional mismatch, as the water supplies for many cities and villages come from watersheds beyond

49. See, e.g., Ford J.H. Turrell, Frack Off! Is Municipal Zoning a Significant Threat to Hyrdaulic Fracturing in Michigan?, 58 WAYNE L. REV. 279, 290-91 (2012) (noting difference in cities' and counties' abilities to use zoning to prevent gas mining).

50. Mich. Const. art. VII.

51. Id. art. VII, § 2 .

52. Id. art. VII, § 17 .

53. Id.

54. See Ford J.H. supra note 49.

55. Мich. СOMP. LAWS $\S \S 45.514,42.1$ (2013).

56. See Typical Organization Chart: General Law Township, Mich. TwP. Ass'N (last visited Jan. 3, 2014), http://www.michigantownships.org/downloads/typical_general_law_ township_organization_chart.pdf.

57. Id. $\S 125.3209$.

58. Mich. Zoning Enabling Act, Mich. CoMP. LAwS ch. 125 (2006).

59. See MiCH. COMP. LAWS $§ 117.4 i(d)$ (2013).

60. See Mich. DePT. Of ENVTl Quality, Hydraulic Fracturing IN Michigan 8 (Apr. 2013) (map of drill sites), archived at http://perma.cc/J2EB-75ZP. 
their borders. ${ }^{61}$ By and through their charters, cities may regulate where the state has not. ${ }^{62}$ Each charter has certain mandatory provisions which form the structure of government and create the rights and responsibilities of the local government. ${ }^{63}$ The ZEA grants legislative authority to chartered local units of government to create policies and ordinances to promote the health, safety, and welfare of the population within the jurisdiction of that local unit. $^{64}$

Local ordinances have a general presumption of validity by courts and require a finding of unreasonableness in order to be overturned. ${ }^{65}$ Generally,

a municipality is precluded from enacting an ordinance if 1) the ordinance is in direct conflict with the state statutory scheme, or 2) if the state statutory scheme preempts the ordinance by occupying the field of regulation which the municipality seeks to enter, to the exclusion of the ordinance, even where there is no direct conflict between the two schemes of regulation. ${ }^{66}$

What the state gives, however, the state may take away. Either through the Constitution or state legislation, local governmental power can be limited. Townships and counties are expressly limited from adopting regulations or controls for oil and natural gas drilling. ${ }^{67}$ Cities and villages, however, do not have the same limitation. ${ }^{68}$ But all is not lost for counties and townships to effectively regulate drilling through other means such as site plan requirements, local health department requirements, ${ }^{69}$ zoning, or traditional nuisance-style regulation. ${ }^{70}$

61. Detroit Water and SeWerage DePT., DWSD FaCt SheET 1 (2013), archived at http://perma.cc/YLB3-VUD6.

62. МiCh. CONST. art. VII, $\S 22$.

63. MiCh. COMP. LAWS $\S 117.3$ (2013).

64. Id. $\S 117.3(\mathrm{j})$.

65. Kyser v. Kasson Twp., 486 Mich. 514, 521 (2010).

66. People v. Llewellyn, 401 Mich. 314, 322 (1977).

67. Мich. COMP. LAWS $\S 125.3205$ (2013) (dictating that a county or township shall not regulate or control the drilling, completion, or operation of oil or gas wells or other wells drilled for oil or gas exploration purposes and shall not have jurisdiction with reference to the issuance of permits for the location, drilling, completion, operation, or abandonment of such wells).

68. Id. While the ZEA generally regulates all local units of government, $\S 125.3205(2)$ specifically preempts only townships and counties rather that utilizing the more general phrase "local units of government" which is utilized elsewhere. Id. This seems, at least arguably, to show an intent that the drafters did not wish to preempt all local units of government but only counties and townships in this area.

69. 2002 Mich. Op. Att'y Gen. 7117 (2002).

70. See infra Part IV.B.iv. 
The style and manner of regulation depend on a number of factors unique to each locality. In the experience of the author, some primary factors include: 1) whether another unit of government shares land area with the unit attempting to regulate, given the hierarchy discussed above; 2) location of potential gas wells within the region; 3) presence of a comprehensive land use plan or zoning board; 4) presence of county health department, or more regional health department; and 5) topographical and demographical makeup of the jurisdictional area. ${ }^{71}$ While this is not an exhaustive list, these are factors to consider when drafting an ordinance. These factors will help ensure that an ordinance does not run afoul of the ZEA. $^{72}$

Local units of government have the ability to promulgate land use zoning ordinances by creating a zoning commission. ${ }^{73}$ The key to whether a "fracking ordinance" would survive judicial scrutiny is whether it does not specifically target hydraulic fracturing but legislates more generally, because most oil and gas regulation is expressly preempted by the state. ${ }^{74}$ In Addison Twp. v. Gout, the Michigan Supreme Court held that while the legislature intended to preempt local regulation of wells (at least by townships, and likely also counties), the location and operation of pipelines was not so preempted. ${ }^{75}$ The Court left the door open by saying that it could find no intent that the legislature expressly intended to preempt "all local regulation of the oil and natural gas industry."76 Therefore, the potential for local regulation by townships and other local units of government exists where the local law does not conflict with the express preemption in the ZEA.

\section{REForming State LAW to BetTER PROTECT THE STATE'S UNIQUe ENVIRONMENTAL RESOURCES FROM FRACKING}

While Michigan has made strides in regulating new fracking wells in the state, refinements and additions are still necessary. There are process limitations due to the antiquated statutory structure and the ability of the Supervisor to make fundamental and necessary changes that protect the environment and public health.

\section{A. Strengthen Public Notice and Comment Requirements}

Under the current permitting program, public notice and the ability to

71. See supra note 1 and accompanying text.

72. MICH. COMP. LAWS $\$ 125.3202$ et. seq. (2013).

73. Мiсн. СоMP. LAWS $\S 125.3301$ (2013).

74. Id. $\S 125.3205$.

75. Addison Twp. v. Gout, 435 Mich. 809, 815 (1990).

76. See id. 
comment is incidental, and there appears to be no requirement for the Supervisor to respond to public comments when issuing or denying a particular permit. Permitting decisions ultimately fall on the Director of the MDEQ and the Supervisor. ${ }^{77}$ When a mineral rights owner wishes to drill, notice is given to the holder of the property where the drilling will take place and to the county clerk. ${ }^{78}$ There does not appear to be any requirement that the DEQ respond to public comments beyond the statutory authority to accept and consider them. ${ }^{79}$

To increase public involvement in this process, the DEQ or Supervisor could issue a rule which creates an additional step between submission of application materials and decision on permit for a public comment period with appropriate public notice. The rule could be tailored specifically for deep well or high volume hydraulic fracturing wells. Increasing notice and providing for a mandatory comment period would allow for public involvement similar to other state permitting programs. Since comments may already be sent to the Supervisor ${ }^{80}$ the solution may simply be more public notice and a required response to comments document from the Supervisor that would be made part of the administrative record. Increased notice could be accomplished through public listing in newspapers, web posting, Twitter, etc. ${ }^{81}$

Michigan's existing statute governing mineral mining provides a good example for improved public notice and comment requirements. First, it utilizes tools such as a mandatory public meeting on the application with notice to local governments, and requires publication in the local newspaper for the mine's proposed location. ${ }^{82}$ After the initial public meeting, the public is given twenty-eight days to provide written comments on the permit application. ${ }^{83}$ Once the department has made an initial decision, (no later than twenty-eight days after comments are received) a second public

77. Mich. Bus. One Stop, Oil \& Gas Drilling, Secondary Recovery, Brine Disposal, and Hydrocarbon Storage, MICHIGAN.GOV, http://michigan.gov/statelicensesearch/0,1607,7-18024786_24821-244649--,00.html (last updated Oct. 2010, archived at http://perma.cc/BB73WHT3).

78. Id.

79. See Mich. Admin. Code r 324.201(4) (2012); Mich. Comp. LaWs § 324.61525(1) (2013).

80. "A city, village, township, or county in which an oil or gas well is proposed to be located may provide written comments and recommendations to the supervisor pertaining to applications for permits to drill and operate. The supervisor shall consider all such comments and recommendations in reviewing the application." MiCH. COMP. LAWS SERV. $\S$ 324.61525(4) (LexisNexis 2013).

81. E.g., "The supervisor shall make available to any person, upon request, not less often than weekly, the following information pertaining to applications for permits to drill and operate" could be changed to read shall make available by posting in all public forums reasonably likely to provide notice to stakeholders. Id. §324.61525(3).

82. Id. § $324.63205(6)$.

83. Id. \& 324.63205(7). 
hearing must be held to discuss the proposed decision. ${ }^{84}$ Notice is distributed to the public in a similar fashion as in the initial public meeting but includes instructions for reviewing the permit application, instructions on where to find the application (which is made available in a local public location), lists of other permits and hearings regarding the proposed mining operation, and finally, the location and time for the next public hearing. ${ }^{85}$ There is then yet another public comment period of twenty-eight days, finally culminating with a summarized report of comments received. ${ }^{86}$ This process must occur prior to granting a permit for mining operations. ${ }^{87}$

While the potential environmental harms from mineral mining may pose a greater risk to visible natural resources in the state than fracking, ${ }^{88}$ the structured notice and comment periods for permitting decisions are helpful to inform the public of potential harm. These requirements also provide an extended review of the actions of regulators by the public to ensure complete adherence to law and protection of the environment and public health.

\section{B. Allowing Local Regulation of Natural Resources in Local Jurisdictions}

All local units of government in Michigan have the power and ability to better involve the public in regulating hydraulic fracturing operations. As a general matter, industry and the state may have an interest in avoiding varying levels of regulation from local units of government. It is likely that any regulation that applies only to fracking operations may be either expressly preempted by statute ${ }^{89}$ or field preempted by Michigan's regulatory scheme. ${ }^{90}$ Local units of government need both the will and resources to meet these challenges. ${ }^{91}$ The best option appears to be the creation of facially neutral zoning, permitting, and ordinance requirements that effectively integrate the local governmental unit into the fracturing process and do not infringe on the state's regulations.

Critical for any local natural resources ordinance is whether the legislation totally excludes a particular industry within the jurisdiction of that local unit of government. In Kyser, the court held that the ZEA

84. Id.

85. Id.

86. Id. § $324.63205(8)$.

87. Id. § 324.63205(9).

88. See Questions and Answers About Hydraulic Fracturing in Michigan, supra note 5 (stating that hydraulic fracturing has not yet been responsible for major environmental damage in Michigan).

89. See Schroeck \& Karisny, supra note 11.

90. Mich. COMP. LAws SERV. § 324.61505 (LexisNexis 2013).

91. It is highly likely that any regulation by local municipalities in this area will result in a legal challenge due both to the financial resources of the energy companies and the necessary statutory interpretation to fit local regulations into the state's regulatory scheme. 
"enable[s] localities to regulate land use to meet the state's needs for natural resources .... it follows that the Legislature intended that localities would be responsible for regulating the extraction of natural resources within their boundaries. ${ }^{, 92}$ The court also noted that the ZEA limits only oil and natural gas drilling, but no other sorts of natural resource extraction. ${ }^{93}$

However, the Michigan Legislature has essentially overruled the Michigan Supreme Court by reinstating the Silva test ${ }^{94}$ for natural resource extraction exclusionary zoning. ${ }^{95}$ The Silva test requires a higher standard of reasonableness for natural resource extraction: "[a]n ordinance shall not prevent the extraction, by mining, of valuable natural resources from any property unless very serious consequences would result from the extraction of those resources ... [those resources are] considered valuable . . if a person ... can receive revenue and reasonably expect to operate at a profit." ${ }^{, 96}$ In determining whether very serious consequences would arise from exploitation of natural resources, six factors are considered: 1) relationship of extraction to existing land uses; 2) impact on existing land uses in the vicinity; 3 ) impact on property values in vicinity of extraction and along routes of ingress and egress; 4) impact on pedestrian and traffic safety in vicinity of property and routes to resources; 5) impact on identifiable health, safety, and welfare interests of the local unit of government; and 6) the overall public health interest in the extraction of those specific natural resources on the property. ${ }^{97}$ The statute states that the test's limitations on the zoning powers of local units of government do not cover regulation of: blasting hours, noise levels, regulation of hours of operation, dust control, and traffic, so long as the regulations are "reasonable in accommodating customary mining operations." 98 Whether these limitations totally bar additional regulation by local units of government is unclear, especially those ordinances which are not facially related to mining or drilling.

As the specific local regulatory proposals discussed below will demonstrate, any regulation which could prevent the extraction of a valuable natural resource may be impermissible. What follows are the strengths and weaknesses of three potential local ordinances: small volume water withdrawal permitting, local health department groundwater withdrawal limitations, and an outright municipal ban on fracking. It is important to remember that the powers and jurisdictional reach of each different type of local governmental unit may limit the applicability of one

92. Kyser v. Kasson Twp., 486 Mich. 514, 542 (2010).

93. Id.

94. See generally Silva v. Ada Twp., 416 Mich. 153 (1982).

95. Мich. COMP. LAWS SERV. §§ 125.3205(3)-(5) (LexisNexis 2013).

96. Id.

97. Id. $\S 125.3205(5)$.

98. Id. $\S 125.3205(6)$ (emphasis added). 
or more of the ideas presented.

\section{Local Water Withdrawal Permitting}

In Michigan, all water withdrawals in excess of 100,000 gallons per day are governed by NREPA, specifically Part 327, Great Lakes Preservation. ${ }^{99}$ However, "[t]he following withdrawals are exempt from the requirements of this part unless they result in a diversion: (a) [a] withdrawal undertaken as part of an activity authorized by the department under part . . . 615." 100 Hydraulic fracturing falls under Part 615 and fracking in Michigan generally results in an intra-basin withdrawal since groundwater is usually pumped from a location near the drilling site, and any water transfer will almost certainly be intra-basin since nearly all of Michigan is within the Great Lakes Basin. ${ }^{101}$ These two statutes, taken together, exempt large volume water withdrawals for oil and gas development, including fracking. ${ }^{102}$ Also, local units of government are further unable to regulate large quantity water withdrawals (100,000 GPD or more) as Part 327 denies local units of government such right. ${ }^{103}$

However, options may still exist to allow regulation of groundwater withdrawals less than 100,000 gallons per day since the statute does not specifically eliminate a local government's ability to regulate these smaller volume water withdrawals. ${ }^{104}$ Such a municipal permit could require, for instance, that prior to receiving the local small quantity water withdrawal permit a site specific review take place ${ }^{105}$ and an adverse water quality assessment be generated by an oil or natural gas driller. This ordinance would have to be carefully tailored to avoid harming other uses that the municipality may not want to impact, such as agriculture or manufacturing. One option is to place these requirements only for non-farm, non-single family home consumptive uses. ${ }^{106}$ Because of the way large volume

99. Id. $\S \S 324.32701-30$.

100. Id. $\S 324.32727(1)$ (a) (referencing id. $\S \S 324.61501-27$ which regulates oil and natural gas by empowering the supervisor of wells) (alterations added).

101. Мich. COMP. LawS SERV. $§ 324.61501$ (LexisNexis 2013); The Great Lakes, GREAT LAKES INFORMATION NETWORK, http://www.great-lakes.net/lakes/ (last updated Dec. 28, 2013, archived at http://perma.cc/AQ98-MRE5).

102. See Mich. COMP. LAWS SERV. § 324.32727(1)(a) (2013) (referencing id. § 324.61501-27, which regulates oil and natural gas by empowering the supervisor of wells).

103. Mich. COMP. LAWS SERV. § 324.32726 (LexisNexis 2013).

104. Id.

105. Id. § $125.3102(\mathrm{~s})$.

106. "Consumptive use" is an apt term for fracking since the liquid used cannot simply be returned to the aquifer after the operation. Instead it is often stored in other injection wells or on the surface. See Basic Information about Injection Wells, EPA, http://water.epa.gov/type/groundwater/uic/basicinformation.cfm (last updated May 4, 2012, archived at http://perma.cc/M52E-QXQK). 
withdrawals are defined within the statute ${ }^{107}$ deep wells might be covered by a 10,000-99,000 gallon per day local permit if the well utilized less than nine million gallons of water during the total fracturing operation, and the ninety day average would be less than a large quantity water withdrawal under part $327 .{ }^{108}$ It is noteworthy, and perhaps ironic, that using a 90-day average for the state regulatory threshold avoids state regulation of many water withdrawals, but opens the door to potentially stricter local regulation.

Local governmental regulation of smaller water withdrawals may still run into several pitfalls. The first relates to the difficulty outlined above: whether a water withdrawal permit requirement counts as a drilling permit. ${ }^{109}$ Drilling permits are expressly prohibited for both counties and townships under the ZEA. ${ }^{110}$ In Dart Energy Corp. v. Iosco Twp., the Michigan Court of Appeals found that "Iosco Township [was] expressly prohibited from regulating an oil and gas well that [was] converted to a brine injection well" under the township zoning enabling act. ${ }^{11}$ While the various zoning enabling acts have since been rewritten and combined ${ }^{112}$ for consistency among local units of government, it is likely that a similar argument could be made against the lower volume water permitting idea. Cities and villages, however, remain exempt from this restriction. ${ }^{113}$

The second potential issue is related to the factors laid out by the Silva court. ${ }^{114}$ Under the test, the issue for a water withdrawal ordinance is whether it prevents the extraction, by mining, of valuable natural resources where there is either a personal or market need for those resources and no very serious consequences would arise from their recovery. ${ }^{115}$ There are two sub-issues here: whether a particular ordinance actually prevents extraction and whether oil and natural gas drilling is considered mining under the act. While the statute outlines factors to be weighed to determine whether very serious consequences would occur if the extraction occurs, "prevention of extraction" remains undefined. ${ }^{116}$ In Velting $v$. Cascade Charter Twp., a zoning ordinance which did not expressly prohibit removal of natural resources, required a special additional permit, and still invoked the "no

107. MiCH. COMP. LAWS SERV. $§ 324.32701$ (LexisNexis 2013). Any withdrawal greater than 100,000 gallons per day on average over a 90-day period is regulated under the statute.

108. Id.

109. See supra notes 28-32 and accompanying text.

110. MiCH. COMP. LAWS SERV. § 125.3205 (LexisNexis 2013).

111. 520 N.W.2d 652 (1994).

112. See e.g., MICH. CoMP. LAwS SeRv. § 125.3101 (LexisNexis 2013) (enacted in 2006).

113. See id $\S 125.3205$ (by implication, i.e., cities and villages not listed for this restriction).

114. See supra note 97 and accompanying text.

115. MiCH. COMP. LAWS SERV. § 125.3205 (LexisNexis 2013).

116. See id. 
very serious consequences" test. ${ }^{117}$ Secondly, mining is not defined within the Michigan ZEA. ${ }^{118} \mathrm{~A}$ reviewing court may determine that there are different standards for oil and gas because oil and gas development are treated separately in the section-the words "oil and gas" are specifically used in (2), but "mining" is used in (3). ${ }^{119}$ According to the legislative history, ${ }^{120}$ the first draft of the amendment re-instating the "no very serious consequences" test did not contain the term "mining" and instead used "natural resources" generally. ${ }^{121}$ "Mining" was added later in the process, presumably to more narrowly tailor the application. ${ }^{122}$

A third potential issue pertains to Michigan's regulatory framework for hydraulic fracturing. Despite the exemption for oil and natural gas drilling operations from the large volume water withdrawal statute, DEQ has required, via a non-legislative rule, a Supervisor of Wells Instruction that drilling operations utilize the water withdrawal assessment tool as required for any other large volume withdrawal. ${ }^{123}$ This requirement by the Supervisor could create a potential problem where the state has essentially "occupied the field" for regulation by requiring water withdrawal analysis at the state level, and thus precluding local municipalities from enacting similar requirements. ${ }^{124}$

\section{Water Withdrawal Regulation and Water Quality Protection from Local Health Departments}

In 2002, then Michigan Attorney General Jennifer Granholm, issued an opinion as to whether a county may regulate water withdrawals from underground aquifers for the purpose of sustaining water quality. ${ }^{125}$ The stated purpose of the regulation was to protect water quality during periods of excessive agricultural withdrawals in the summer months, which resulted

117. Velting v. Cascade Charter Twp., No. 283638, 2009 WL 3013202 (Mich. Ct. App. Aug. 22, 2009).

118. MiCH. COMP. LAWS SERV. $\S 125.3102$ et seq. (LexisNexis 2013).

119. See id. § 125.3205 .

120. In re Certified Question from U.S. Ct. App. for the 6th Cir., 659 N.W.2d 597, 60002 (Mich. 2003) (finding that statutory history could not be used because there was no ambiguity); see also Mayor of Lansing v. Mich. PSC, 680 N.W.2d 840, 846-47, rev'd on other grounds (rejecting use of statutory history and explaining ambiguity standard).

121. Id. $\S 125.3205$.

122. H.B. 4746, 96th Leg., Gen. Sess. (Mich. 2011).

123. Office of Geological Survey Department of Environmental Quality, Hydraulic Fracturing of NatURAL Gas Wells IN Michigan (May 31, 2011), archived at http://perma.cc/63XX-7M5V.

124. See Addison Twp. v. Gout, 460 N.W.2d 215, 217 (1990) (describing the issue of field preclusion as applying even where there is no direct conflict between state and local unit schemes of regulation).

125. Op. Mich. Att'y Gen. No. 7117 (Sept. 11, 2002). 
in reduced drinking water quality for residential wells. ${ }^{126}$ While the opinion does not speak directly to groundwater withdrawals for hydraulic fracturing purposes, much of the opinion is instructive here.

The opinion focuses on a potential local health department approach to regulation of well water withdrawals. ${ }^{127}$ Specifically, the Attorney General stated:

[i]t is my further opinion that a local health department may, by regulation, limit the amount of well water that may be withdrawn from an underground aquifer, even though the department has issued a permit to construct a well in the same aquifer, provided that (i) the regulation is necessary or appropriate to safeguard the public health; (ii) the regulation is not more restrictive than necessary to address the threat to the public health; and (iii) the regulation is at least as stringent as any standard established by state law applicable to the same or a similar subject matter. ${ }^{128}$

Local health departments may promulgate laws under the auspices of "prevent[ing] disease, prolong[ing] life, and promot[ing] the public health . . . including prevention and control of environmental health hazards." ${ }^{.129} \mathrm{~A}$ county or district health department could likewise protect citizens from harms caused by excessive water withdrawals for fracking oil or natural gas wells. The key question is whether a court would find that such a health regulation is necessary or appropriate to safeguard the public health. ${ }^{130}$

A recent Michigan Court of Appeals decision in McNeil v. Charlevoix County not only held that county (or district) health departments may regulate, even where there is state statutory requirements on point with the health organization's regulation, but also that "the [1]egislature has not expressly limited the exact manner in which a local health department prevents and controls health hazards within its communities."131 In McNeil, the Northwest Michigan Community Health Agency (NMCHA) promulgated a rule prohibiting smoking in all public places but required that "employers who do not wholly prohibit smoking at an enclosed place of employment must designate an NMCHA-approved smoking room" in their place of business. ${ }^{132}$ The regulation also prohibited an employer from discharging an individual who sought to enforce the regulation against his

126. Id.

127. Id.

128. Id. at 3 (alteration added).

129. МiсH. COMP. LAWS SERV. $\S 333.2433$ (LexisNexis 2013) (alterations added).

130. See Op. Mich. Att'y Gen., supra note 125 , at 2.

131. McNeil v. Charlevoix Cnty., 772 N.W.2d 18, 26 (2009) (alteration added).

132. Id. at 21 . 
or her employer. ${ }^{133}$ The court held that despite the legislature having passed the Michigan Indoor Clean Air Act, which also regulates smoking in public places, the field was not occupied by the statute and that the regulation was not expressly preempted by the statute. ${ }^{134}$ The court found that the district health department could promulgate rules for smoking so long as they were not less restrictive than the state's law and so long as they protected the public health. ${ }^{135}$ Finally, the court went so far as to allow the health department the substantial leeway of essentially barring an employer from firing an at-will employee who sought to enforce the regulation as within the health department's power. ${ }^{136}$ Once the regulation is approved by the controlling counties, it is akin to a legislative enactment which would limit the common law presumption against limiting the at-will employment rights of employers. ${ }^{137}$

While McNeil does not specifically address fracking, it does illustrate the discretion that Michigan courts give to health department rules. The court was willing to extend to the health department essentially full legislative power to effectuate policy that, in the name of protecting residents' health, abrogated long-held employer rights. It would hardly be a stretch to intuit that health departments could take the fundamentally less restrictive measure of limiting well drillers' ability to withdraw water from county aquifers where it would cause adverse health effects.

Local health departments in particular have the power to regulate in the environmental arena under several statutory provisions. The first, section 333.2433 of Michigan Compiled Laws, states that it is the duty of the local health department to prevent and control environmental health hazards. ${ }^{138}$ Additional provisions grant the health department the power to adopt regulations necessary to implement its duty (to prevent environmental hazards) ${ }^{139}$ The third provision grants to local health departments the power to "[a]dopt regulations to properly safeguard the public health and to prevent the spread of diseases and sources of contamination." 140 These three provisions grant local health departments the ability to study the potential for groundwater contamination as a result of fracturing, or water quality degradation resulting from over-withdrawal during fracturing operations and to promulgate rules to avoid these potential health problems. The violation of a health department regulation does not necessarily result in a cause of action against the drilling company or permitting entity, but rather

133. Id.

134. Id. at 23.

135. Id.

136. Id. at 34 .

137. Id. at 24.

138. Id. (LexisNexis 2013).

139. Id. § 2441 .

140. Id. $\S 2435$ (alteration added). 
incurs fines and penalties as defined by statute. ${ }^{141}$

\section{Effectiveness and Legality of Municipal Bans on Fracking}

The issues raised above ${ }^{142}$ in the discussion of low volume water withdrawal ordinances are also relevant when evaluating a full-scale municipal fracking ban. Statutory interpretation will determine whether a municipal ban at the city or village level is possible after the passage of Public Act $113,{ }^{143}$ which re-instated the Silva test. ${ }^{144}$ As discussed previously, the test employs a greater standard of reasonableness for zoning plans that affect natural resources. ${ }^{145}$ If a zoning ordinance prevents the extraction of a valuable natural resource, the municipality must show that the public interest in prevention of extraction outweighs the public interest in the extraction of those resources. ${ }^{146}$ There are several potential issues with a municipal ban under a Silva analysis.

There is no question as to whether a ban constitutes prevention of utilization of natural resources under the Silva test. ${ }^{147}$ There is, however, still the issue as to whether oil and gas extraction is included in the word "mining." In the statute, mining is mentioned several times, but only in its traditional meaning - the extraction of solid natural resources from the earth. ${ }^{148}$ In Weaver v. Richards, the court stated that "the words 'mineral' or 'minerals,' without any qualification, would include both oil and gas, and that therefore a reservation of minerals in place in the earth would include both gas and oil."149 There is then a potential statutory interpretation question open for a local municipality: if natural gas is considered a mineral under Michigan law, then it is conceivable that it must be "mined" under the statute, and thus falls under the reinstated Silva test.

The Silva test is further explored in American Aggregates Corp. v. Highland Twp. ${ }^{150}$ In American Aggregates, the Michigan Court of Appeals

141. "[A] person who violates a regulation of a local health department or order of a local health officer under this act is guilty of a misdemeanor punishable by imprisonment for not more than 6 months or a fine of not more than $\$ 200.00$, or both." MICH. COMP. LAWS SERV. $\S 2443$ (LexisNexis 2013) (alteration added).

142. See supra Part IV.B.i.

143. 2011 Mich. Legis. Serv. 113 (LexisNexis).

144. Silva v. Ada Twp., 416 Mich. 153, 159 (1982).

145. Id. at 159.

146. $I d$.

147. MiCh. COMP. LAWS SERV. § 125.3205 (Lexis 2013).

148. See, e.g., id. (word mine or mining only appears in this single section of the statute, where it is not defined).

149. 156 Mich. $320,324,120$ N.W. 818, 819 (1909).

150. Am. Aggregates Corp. v. Highland Twp., 151 Mich. App. 37, 390 N.W.2d 192 (1986). 
applied the Silva test to a gravel mine. ${ }^{151}$ The plaintiff attempted to have his property rezoned from general agricultural to industrial, which would have allowed for extraction of gravel on the premises, but was denied by the township. ${ }^{152}$ The trial judge determined that the plaintiff "failed to show that no 'very serious consequences' would result from [gravel extraction]." ${ }^{153}$ The appellate court held that the "no very serious consequences" test is a sliding scale involving something of a cost benefit analysis where the benefits of extraction must outweigh the costs incurred by the public due to the extraction of these resources. ${ }^{154}$ Because there was not a high demand for gravel in Southeast Michigan at the time, the court found that there was a low public interest in extraction. ${ }^{155}$ The low interest in extraction was weighed against the public costs of increased truck traffic to the site with greater potential for accidents and noise, decreased property values for surrounding landowners if the gravel pit was built on that site, and damage to the township's planned residential developments and property tax base. ${ }^{156}$

One may generally state that the success of a municipal fracking ban depends on the specific facts surrounding the proposed well and the local character of the region. If, as in American Aggregates, the drilling operation were to occur in an area with an already large number of oil or natural gas wells in operation, and there were heavy, calculable costs that the new well might impose on the community, the zoning ordinance would likely stand. ${ }^{157}$ However, if the well were located in an area that does not create problems that rise to the level of American Aggregates, such as in Silva, ${ }^{158}$ where the extraction area was time and size limited, while providing large public benefits relative to limited externalized cost, the ordinance likely will not stand. ${ }^{159}$ Residential municipalities may have greater success with a fracking ban as the harms from drilling may be enough to allow the ordinance to stand, so long as the need for oil and natural gas is not too high in the surrounding area. Of course, this is not an ideal situation for rural areas where traditional nuisance-style claims may not be as applicable due to lower population density. A finding of "very serious consequences" might also arise if a determination is made by the United States Environmental Protection Agency or DEQ that fracking operations

151. Id. at 44 .

152. Id. at 40 .

153. Id. at 42 (alteration added).

154. Id. at 44 (paraphrasing Compton Sand and Gravel v. Dryden Twp., 125 Mich. App. $383 ; 336$ N.W.2d 810 (1983)).

155. Id. at 46.

156. Id. at $47-50$.

157. See id.

158. Silva v. Ada Twp., 416 Mich. 153 (1982).

159. See id. 
contribute to local groundwater contamination or other public health issues. ${ }^{160}$

\section{Utilizing Traditional Nuisance Regulations to Limit Fracking Impacts}

None of the traditional ordinance powers of local units of government to control nuisance-like harms have been removed by statute. ${ }^{161}$ Townships and counties have considerably less leeway in this area because the same statute expressly preempts their ability to regulate oil and natural gas production. ${ }^{162}$ Local units of government continue to have legislative power to regulate local concerns such as noise, traffic, and dust, ${ }^{163}$ which-while not specifically providing more local control of fracking operations-do provide for some oversight in controlling land use in their communities.

Recent regulatory changes promulgated by the DEQ have largely supplanted traditional nuisance regulations by providing for standards and a definition for "nuisance." 164 To the extent that the legislation redefining "nuisance noise" redefines the property right to quiet use and enjoyment, a court could consider it a taking. ${ }^{165}$ While it seems unlikely that a state executive agency could supplant local authority through regulations, the issue has not been explored regarding oil and natural gas wells. Perhaps the inclusion simply adds an additional arrow to the quiver of an annoyed neighbor, or perhaps local governments have lost even more of their traditional Home Rule powers to regulate merely the most local of concerns-obnoxious noise.

160. See supra note 72 and accompanying text.

161. See Mich. COMP. LAwS SERV. $\S 125.3205(6)$ (LexisNexis 2013) (specifying that subsections 3 through 5 which reinstated the Silva test do not limit traditional reasonable regulatory powers of municipalities such as hours of operation, blasting hours, noise levels, dust control measures, and traffic, so long as they are not tailored to addressing nonferrous mineral mining, which has comprehensive statutory requirements in this area).

162. Id. at $\S 125.3205(2)$.

163. See, e.g. City of Detroit v Quails, 434 Mich. 340, 362 (1990).

164. MiCH. ADMN. CODE r. 324.1015 (2013) ("'Nuisance noise' means any noise from a well or its associated surface facilities that causes injurious effects to human health or safety or the unreasonable interference with the comfortable enjoyment of life or property.").

165. See Bormann v. Kossuth Cnty. Bd. of Sup'rs, 584 N.W.2d 309, 316-17, 321 (lowa 1998) (finding that right-to-farm legislation preventing nuisance suits creates easements on neighboring land which was an unconstitutional taking); but see Moon v. N. Idaho Farmers Ass'n, 96 P.3d 637, 644-45 (Idaho 2004) (discussing Bormann and declining to adopt it in Idaho). See Adam Van Buskirk, Right-To-Farm Laws as "Takings" in Light of Bormann v. Board of Supervisors and Moon V. North Idaho Farmers Association, 11 Alb. L. Envt'l Outlook 177, $177-87$ (explaining and analyzing Bormann and Moon); and 2002 L. Rev. M.S.U.-D.C.L. 213, 228-35 (analyzing Michigan's right-to-farm law in light of Bormann). 


\section{CONCLUSION}

While federal and state regulations continue to lack clear, focused environmental protections from hydraulic fracturing, there are several options available for local units of government to ensure that the environment and public health are not subjected to unreasonable harm from oil and gas development. Michigan, at both the state and local level, has a heightened duty as the steward of a truly unique international resource to protect the water in the Great Lakes Basin, held in Public Trust for future generations. 